\title{
Heterogeneous reactions of carbonyl sulfide on mineral oxides: mechanism and kinetics study
}

\author{
Y. Liu, J. Ma, and H. He \\ State Key Laboratory of Environmental Chemistry and Ecotoxicology, Research Center for Eco-Environmental Sciences, \\ Chinese Academy of Sciences, Beijing, 100085, China
}

Received: 20 April 2010 - Published in Atmos. Chem. Phys. Discuss.: 10 May 2010

Revised: 29 September 2010 - Accepted: 1 October 2010 - Published: 4 November 2010

\begin{abstract}
The heterogeneous reactions of carbonyl sulfide (OCS) on the typical mineral oxides in the mineral dust particles were investigated using a Knudsen cell flow reactor and a diffuse reflectance UV-vis spectroscopy. The reaction pathway for OCS on mineral dust was identified based on the gaseous products and surface species. The hydrolysis of OCS and succeeding oxidation of intermediate products readily took place on $\alpha-\mathrm{Al}_{2} \mathrm{O}_{3}, \mathrm{MgO}$, and $\mathrm{CaO}$. Reversible and irreversible adsorption of OCS were observed on $\alpha-\mathrm{Fe}_{2} \mathrm{O}_{3}$ and $\mathrm{ZnO}$, respectively, whereas no apparent uptake of OCS by $\mathrm{SiO}_{2}$ and $\mathrm{TiO}_{2}$ was observed. The reactivity of OCS on these oxides depends on both the basicity of oxides and the decomposition reactivity of oxides for $\mathrm{H}_{2} \mathrm{~S}$. Based on the individual uptake coefficients and chemical composition of authentic mineral dust, the uptake coefficient $\left(\gamma_{\mathrm{BET}}\right)$ of mineral dust was estimated to be in the range of $3.84 \times 10^{-7}$ $2.86 \times 10^{-8}$. The global flux of OCS due to heterogeneous reactions and adsorption on mineral dust was estimated at $0.13-0.29 \mathrm{Tg} \mathrm{yr}^{-1}$, which is comparable to the annual flux of OCS for its reaction with $\cdot \mathrm{OH}$.
\end{abstract}

\section{Introduction}

Carbonyl sulfide (OCS) is a predominant sulfur containing compound in the atmosphere, with a rather uniform mixing ratio of about $500 \mathrm{pptv}$ in the troposphere (Chin and Davis, 1995). About $0.64 \mathrm{Tg} \mathrm{yr}^{-1}$ of OCS in the troposphere is transported to the stratosphere, where it can be photodissociated as well as oxidized via reactions with $\mathrm{O}\left({ }^{3} \mathrm{P}\right)$ atoms and

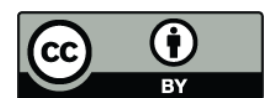

Correspondence to: $\mathrm{H}$. He

(honghe@ rcees.ac.cn)
$\mathrm{OH}$ radicals to form sulfate aerosols. Therefore, it has been considered to be a major source of the stratospheric sulfate aerosol (SSA) during volcanic quiescent periods (Andreae and Crutzen, 1997; Crutzen, 1976; Notholt, 2003; Turco et al., 1980). Because the SSA plays an important role in the Earth's radiation balance, global climate (Anderson, et al., 2003; Graf, 2004; Jones et al., 1994), and stratospheric ozone depletion (Andreae and Crutzen, 1997; Solomon et al., 1993), the investigation about the sources and sinks of OCS in the troposphere is very significant in atmospheric chemistry.

In the past decades, the heterogeneous reactions of trace gases in the atmosphere on atmospheric particles has become increasingly important (Ravishankara, 1997), because they not only account for the alteration of the particulate composition and its surface properties (Aubin and Abbatt, 2006; Jang et al., 2002), but also affect the sources and sinks of trace gases (Jacob, 2000). Several atmospheric modelling studies have shown that atmospheric particles often act as a sink for certain species (Dentener et al., 1996; Usher et al., 2003b). A major contributor to the loading of atmospheric particles is mineral dust, which originates mainly from arid and semi-arid regions with global source strength of about 1000-3000 $\mathrm{Tg} \mathrm{yr}^{-1}$ (Dentener et al., 1996). The surface oxygen, hydroxyl group, absorbed water and defect sites on mineral oxides may provide reactive sites for the heterogeneous uptake of trace gases. Recently, using infrared spectroscopy, a few researchers have reported the heterogeneous reactions mechanism of OCS on atmospheric particles, and mineral oxides including $\mathrm{Al}_{2} \mathrm{O}_{3}, \mathrm{SiO}_{2}, \mathrm{Fe}_{2} \mathrm{O}_{3}, \mathrm{CaO}, \mathrm{MgO}, \mathrm{MnO}_{2}$ and the mixture of $\mathrm{Fe}_{2} \mathrm{O}_{3}$ and $\mathrm{NaCl}$ (Chen et al., 2007; He et al., 2005; Liu et al., 2006, 2007a, b, 2009a; Wu et al., 2004, 2005). In these studies, hydrogen thiocarbonate $\left(\mathrm{HSCO}_{2}^{-}\right)$ was found as a key intermediate (He et al., 2005; Liu et al.,

Published by Copernicus Publications on behalf of the European Geosciences Union. 
2006, 2007a, b, 2009a). Gaseous carbon dioxide $\left(\mathrm{CO}_{2}\right)$ and surface sulfate $\left(\mathrm{SO}_{4}^{2-}\right)$ were found to be the gaseous and surface products (Chen et al., 2007; He et al., 2005; Liu et al., 2006, 2007a, b, 2009a), respectively. Surface sulfite and element sulfur (Wu et al., 2004, 2005) were also observed as surface sulfur species. Additionally, gaseous hydrogen sulfide $\left(\mathrm{H}_{2} \mathrm{~S}\right)$ was detected as one of the hydrolysis products for the heterogeneous reaction of OCS on $\mathrm{MgO}$ and $\mathrm{Al}_{2} \mathrm{O}_{3}$ ( $\mathrm{Liu}$ et al., 2007a, 2008b, c, 2009b). The previous works demonstrate that heterogeneous reactions on mineral dust may be a potential sink for OCS in the troposphere. However, besides on $\mathrm{Al}_{2} \mathrm{O}_{3}$ and $\mathrm{MgO}$, the reactions on all of the other oxides were mainly investigated using infrared spectroscopy with a high OCS concentration. Thus, the reaction pathway on these mineral oxides still needs to be further identified by other experimental methods. In particular, the difference in reaction pathway on these oxides is unclear. On the other hand, the significance of these reactions on the global chemical cycle of OCS depends on its reaction rates or uptake coefficients. However, at present day, the uptake coefficients of OCS on the typical mineral oxides are very limited. Therefore, the kinetic study for the heterogeneous reactions of OCS on mineral dust is necessary.

In this article, we further investigated the heterogeneous reactions of OCS on the typical mineral oxide components in atmospheric particles, including $\mathrm{SiO}_{2}, \mathrm{CaO}, \alpha-\mathrm{Fe}_{2} \mathrm{O}_{3}, \mathrm{ZnO}$ and $\mathrm{TiO}_{2}$, in addition to $\alpha-\mathrm{Al}_{2} \mathrm{O}_{3}$ and $\mathrm{MgO}$ in our previously works (Liu et al., 2008b, c, 2009b), by using a Knudsen cell reactor and a diffuse reflectance UV-vis spectroscopy. We found that the reactions could readily take place on some mineral oxides and some differences in reaction pathway exist on these oxides. We discussed the environmental implications for these reactions based on the uptake coefficients measured by using Knudsen cell reactor.

\section{Experimental section}

\subsection{Materials}

All of the chemicals were used as received, including: carbonyl sulfide (OCS, $1.98 \%$, OCS/ $\mathrm{N}_{2}$, Scott Specialty Gases Inc.), $\mathrm{N}_{2}$ and $\mathrm{O}_{2}$ (99.99\% purity, Beijing AP Beifen Gases Inc.) and $\mathrm{C}_{2} \mathrm{H}_{5} \mathrm{OH}(99.7 \%$, Beijing Chemicals Factory).

According to the main composition of authentic mineral dust (He et al., 2005) and the upper continental crust (Usher et al., 2003a), $\mathrm{SiO}_{2}, \alpha-\mathrm{Al}_{2} \mathrm{O}_{3}, \mathrm{CaO}, \mathrm{MgO}, \alpha-\mathrm{Fe}_{2} \mathrm{O}_{3}, \mathrm{ZnO}$ and $\mathrm{TiO}_{2}$ were chosen as model dust samples. $\alpha-\mathrm{Al}_{2} \mathrm{O}_{3}$ was prepared through calcining $\mathrm{AlOOH}$ (Shandong Alumina Corpartion) at $1473 \mathrm{~K}$ for $3 \mathrm{~h}$. The others are of analytic purity grade, including $\mathrm{SiO}_{2}$ and $\mathrm{TiO}_{2}$ (Beijing Yili Fine Chemicals Co. Ltd), $\alpha-\mathrm{Fe}_{2} \mathrm{O}_{3}$ (Beijing Nanshang Chemicals Factory), $\mathrm{CaO}$ and $\mathrm{ZnO}$ (Shantou Nongxi Chemicals Factory Guangdong) and $\mathrm{MgO}$ (Tianjin Hangu Haizhong Chemicals Factory).

\subsection{Characterisation of sample}

$\mathrm{X}$-ray powder diffraction pattern was collected from 10 to $90^{\circ} 2 \theta$ on a D/max-RB automatic powder X-ray diffractometer using $\mathrm{Cu} \mathrm{K} \alpha$ irradiation. Nitrogen Brunauer-EmmettTeller (BET) physisorption measurement was performed with a Micromeritics ASAP 2000 analyzer.

\subsection{Experimental methods}

KCMS experiment. A Knudsen cell reactor coupled to a quadrupole mass spectrometer (KCMS, Hiden, HAL 3F PIC) was used to study the reaction pathway and to measure the uptake coefficients of OCS on the mineral oxides. The apparatus was described in details in our previous works (Liu et al, 2008b, c). In brief, the mass spectrometer was housed in a vacuum chamber equipped with a $300 \mathrm{~L} \mathrm{~s}^{-1}$ turbomolecular pump (Pfeiffer) and an ion gauge (BOC Edward). The vacuum chamber between the quadrupole mass spectrometer (QMS) and the Knudsen cell reactor was pumped by a $60 \mathrm{~L} \mathrm{~s}^{-1}$ turbomolecular pump for differential pumping of the mass spectrometer and an ion gauge (both from BOC Edward). The Knudsen cell reactor consists of a stainless steel chamber with a gas inlet controlled by a leak valve, an escape aperture whose area could be adjusted with an adjustable iris and a sample holder attached to the top ceiling of a circulating fluid bath. The sample in the sample holder can be exposed or isolated to the reactants by a lid connected to a linear translator. All exposed interior surfaces including the surface of the sample holder were coated with Teflon to provide a chemically inert surface. Blank experiments revealed that there was no uptake due to the fresh sample holder.

The oxide samples were dispersed evenly on the sample holder with alcohol and then dried at $393 \mathrm{~K}$ for $2 \mathrm{~h}$. The pretreated samples and the reactor chamber were evacuated at $323 \mathrm{~K}$ for $6 \mathrm{~h}$ to reach a base pressure of approximately $5.0 \times 10^{-7}$ Torr. After the system was cooled to $300 \mathrm{~K}$, the sample cover was closed. $1.51 \%$ of OCS gas balanced with simulated air $\left(21 \% \mathrm{O}_{2}\right.$ and $\left.79 \% \mathrm{~N}_{2}\right)$ was introduced into the reactor chamber through a leak valve. The relative humidity in the reactant gases was measured as $7 \%$ using a hygrometer (Center 314) with a relative error of $\pm 1.5 \%$. The pressure in the reactor was measured using an absolute pressure transducer. Prior to the experiments, the reactor chamber was passivated with OCS in air for $150 \mathrm{~min}$ to a steady state of QMS signal established as the oxide samples were isolated from the gas by the sample cover. Uptake measurements on all samples were obtained with an average OCS partial pressure of $5.3 \pm 0.3 \times 10^{-6}$ Torr, which was equivalent to $1.7 \pm 0.2 \times 10^{11}$ molecules $\mathrm{cm}^{-3}$ or $7.0 \pm 0.3 \mathrm{ppbv}$. The uptake coefficients were calculated based on the KCMS signal. According to the pressure in the vacuum chamber and the pumping speeds of turbomolecular pumps, the mass signal intensity of OCS could be converted to a flow rate of molecules into the reactor. Then adsorption capacity of OCS 
on mineral oxides could be calculated from the integrated area of a flow rate of molecules into the reactor versus time.

$U V$-vis experiment. The surface sulfur species on oxides after heterogeneous reaction with OCS were identified using a diffuse reflectance UV-vis Spectrophotometer (U-3310, Hitachi). $100 \mathrm{mg}$ of mineral oxides in a quartz tube were exposed to $1000 \mathrm{ppmv}$ of OCS/air in the flow of $100 \mathrm{~mL} \mathrm{~min}^{-1}$ for $9 \mathrm{~h}$ at $300 \mathrm{~K}$, and then the UV-vis spectra were collected promptly using the corresponding pure oxides as reference samples.

\section{Results and discussion}

\subsection{Characterisations}

$\mathrm{XRD}$ results indicate that these oxides used in the experiment are quartz $\left(\mathrm{SiO}_{2}\right)$, corundum $\left(\alpha-\mathrm{Al}_{2} \mathrm{O}_{3}\right)$, lime $(\mathrm{CaO})$ (there is a small amount of $\mathrm{Ca}(\mathrm{OH})_{2}$ in $\mathrm{CaO}$ sample because of its strong basicity and hygroscopicity), hematite $\left(\alpha-\mathrm{Fe}_{2} \mathrm{O}_{3}\right)$, periclase $(\mathrm{MgO})$, spartalite $(\mathrm{ZnO})$ and anatase $\left(\mathrm{TiO}_{2}\right)$, respectively. The detailed information was described elsewhere (Liu et al., 2007b).

The surface areas of these oxides are almost in the same order and close to the value of the authentic atmospheric particles (He et al., 2005) as shown in Table 1.

\subsection{Uptake of OCS and desorption behaviour of surface species on mineral oxides}

$\alpha-\mathrm{Al}_{2} \mathrm{O}_{3}$ and $\mathrm{MgO}$. In our previous works (Liu et al., 2005, 2006, 2008b, c and 2009b), we have reported the hydrolysis reaction and oxidation pathways of OCS on $\mathrm{Al}_{2} \mathrm{O}_{3}$ and $\mathrm{MgO}$. To facilitate the comparison, the Knudsen cell results on $\alpha-\mathrm{Al}_{2} \mathrm{O}_{3}$ and $\mathrm{MgO}$ were also described here briefly and shown in Fig. S1 and S2. As shown in Fig. S1, the consumption of OCS and desorption of $\mathrm{CO}_{2}$ and $\mathrm{H}_{2} \mathrm{~S}$ after the reaction could be seen clearly when $50.2 \mathrm{mg} \alpha-\mathrm{Al}_{2} \mathrm{O}_{3}$ was exposed to $5.3 \pm 0.3 \times 10^{-6}$ Torr of OCS at $300 \mathrm{~K}$. Figure S2 shows the heterogeneous reaction of OCS on $100.0 \mathrm{mg}$ of $\mathrm{MgO}$ at $300 \mathrm{~K}$, the uptake of OCS $(\mathrm{m} / \mathrm{e}=60)$ was accompanied by the production of $\mathrm{CO}_{2}(m / e=44)$ and $\mathrm{H}_{2} \mathrm{~S}(m / e=34)$ on $\mathrm{MgO}$. Based on the discussion in the previous work (Liu et al., 2006, 2007a, 2008b, 2009a; He et al., 2005; Wu et al., 2004, 2005), we can conclude that hydrolysis and oxidation reactions of OCS occurred on $\alpha-\mathrm{Al}_{2} \mathrm{O}_{3}$ and $\mathrm{MgO}$.

$\mathrm{CaO}$. Figure 1 shows the heterogeneous reactions of OCS on $100.4 \mathrm{mg}$ of $\mathrm{CaO}$ at $300 \mathrm{~K}$. Although $\mathrm{CaO}$ and $\mathrm{MgO}$ are the type of $F C C$ crystalline of alkaline earth oxide, the uptake profiles of OCS on them were quite different. The uptake profile on $\mathrm{CaO}$ is also different from that on $\alpha-\mathrm{Al}_{2} \mathrm{O}_{3}$ (Fig. S1). The uptake of OCS on $\mathrm{CaO}$ was accompanied by the production of $\mathrm{CO}_{2}$, while no formation of $\mathrm{H}_{2} \mathrm{~S}$ was detected. In our previous work (Liu et al., 2007b), surface species including $\mathrm{CO}_{3}^{2-}, \mathrm{HCO}_{3}^{-}, \mathrm{SO}_{4}^{2-}$ and $\mathrm{SO}_{3}^{2-}$ were observed while no surface HS was observed during the hetero-

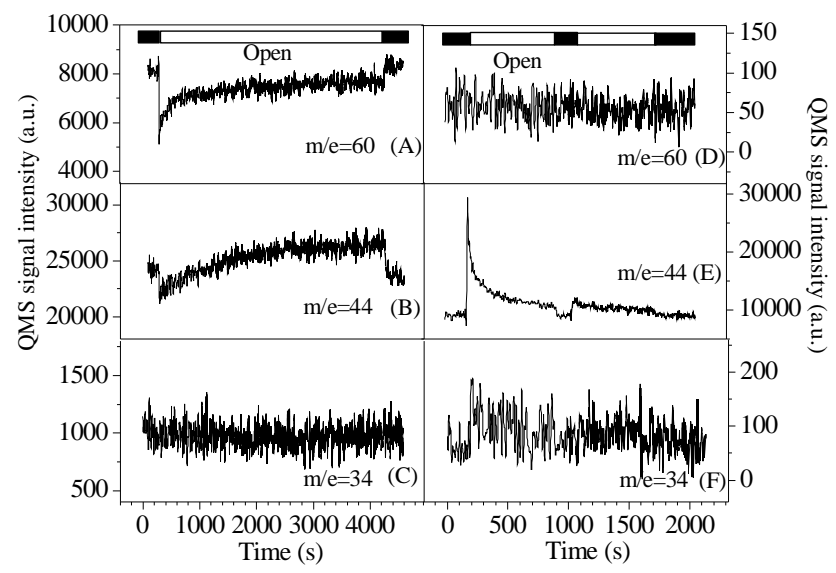

Fig. 1. The heterogeneous reaction of OCS on $100.4 \mathrm{mg}$ of $\mathrm{CaO}$ at $300 \mathrm{~K}$ (left side) and the in situ desorption of surface species in the end of uptake (right side).

geneous reaction of OCS on $\mathrm{CaO}$ using in situ DRIFTS. In addition, except for $\mathrm{CO}_{2}$, no desorptions of OCS and $\mathrm{H}_{2} \mathrm{~S}$ were observed in in situ desorption experiment (Fig. 1d-f). These results suggest that the reaction pathway of OCS on $\mathrm{CaO}$ might be different from that on $\mathrm{MgO}$ and $\alpha-\mathrm{Al}_{2} \mathrm{O}_{3}$. However, it should be pointed out that if $\mathrm{H}_{2} \mathrm{~S}$ produced by heterogeneous reaction on the surface of oxides can be easily and quickly transformed into other species, it is hard to detect the surface $\mathrm{HS}$ or gaseous $\mathrm{H}_{2} \mathrm{~S}$ in DRIFTS and KCMS experiments.

$\alpha-\mathrm{Fe}_{2} \mathrm{O}_{3}$ and $\mathrm{ZnO}$. Figures 2 and 3 show the heterogeneous uptake of OCS and desorption of surface species on $141.3 \mathrm{mg}$ of $\alpha-\mathrm{Fe}_{2} \mathrm{O}_{3}$ and $200.9 \mathrm{mg}$ of $\mathrm{ZnO}$ at $300 \mathrm{~K}$, respectively. As the sample cover was opened, the mass signal intensity of OCS $(m / e=60)$ decreased dramatically on the two samples (Figs. 2a and 3a). Although the total surface areas of $\alpha-\mathrm{Fe}_{2} \mathrm{O}_{3}$ and $\mathrm{ZnO}$ in this experiment were lower than that of $\alpha-\mathrm{Al}_{2} \mathrm{O}_{3}, \mathrm{MgO}$ and $\mathrm{CaO}$, the dropping amplitude for the relative intensity of OCS in Figs. $2 \mathrm{a}$ and $3 \mathrm{a}$ were much larger than that in Figs. S1, S2 and 1. However, the signal intensity of OCS quickly recovered to its baseline within $10 \mathrm{~min}$. It suggests that the active sites for effectively uptaking OCS onto $\alpha-\mathrm{Fe}_{2} \mathrm{O}_{3}$ and $\mathrm{ZnO}$ are abundant, while they have lower catalytic reactivity for OCS hydrolysis or oxidation. In Figs. 2 and 3, the signal intensity for $\mathrm{CO}_{2}$ increased a little, and the signal intensity for $\mathrm{H}_{2} \mathrm{~S}$ hardly changes. At the end of the uptake experiment, as for $\alpha-\mathrm{Fe}_{2} \mathrm{O}_{3}$, desorption of OCS was distinct (Fig. 2d), while desorption of $\mathrm{CO}_{2}$ was weak (Fig. 2e) and no desorption of $\mathrm{H}_{2} \mathrm{~S}$ (Fig. 2f) was observed. For $\mathrm{ZnO}$, no desorptions of OCS, $\mathrm{CO}_{2}$ and $\mathrm{H}_{2} \mathrm{~S}$ were observed as shown in Fig. $3 \mathrm{~d}-\mathrm{f}$ even when the escape hole was increased to its upper limit. These results suggest that OCS might be reversibly adsorbed on $\alpha-\mathrm{Fe}_{2} \mathrm{O}_{3}$ and irreversibly adsorbed on $\mathrm{ZnO}$. In order to confirm these processes, the repeated uptake experiments were further carried 
Table 1. Uptake coefficients and adsorption capacities of OCS on mineral oxides.

\begin{tabular}{|c|c|c|c|c|c|}
\hline Oxide & $\begin{array}{l}S_{\mathrm{BET}} \\
\left(\mathrm{m}^{2} \mathrm{~g}^{-1}\right)\end{array}$ & $\begin{array}{l}\text { Slope } \\
\left(\mathrm{mg}^{-1}\right)\end{array}$ & & $\begin{array}{l}\text { ke coefficient } \\
\text { (BET) }\end{array}$ & $\begin{array}{l}\text { Adsorption capacity } \\
\left(\text { molecules } \mathrm{g}^{-1} \text { ) }\right.\end{array}$ \\
\hline \multirow[t]{2}{*}{$\alpha-\mathrm{Al}_{2} \mathrm{O}_{3}$} & 12.00 & $1.13 \pm 0.13 \mathrm{E}-5$ & Ini & 4.95E-07 & $2.93 \mathrm{E} 18$ \\
\hline & & $1.62 \pm 0.27 \mathrm{E}-6$ & SS & 7.10E-08 & \\
\hline \multirow[t]{2}{*}{$\mathrm{MgO}$} & 14.59 & $1.34 \pm 0.17 \mathrm{E}-5$ & Ini & 4.83E-07 & 4.62E18 \\
\hline & & $4.67 \pm 1.14 \mathrm{E}-6$ & SS & $1.68 \mathrm{E}-07$ & \\
\hline \multirow[t]{2}{*}{$\mathrm{CaO}$} & 6.08 & $7.32 \pm 0.19 \mathrm{E}-6$ & Ini & 6.33E-07 & $1.48 \mathrm{E} 17$ \\
\hline & & $8.89 \pm 2.02 \mathrm{E}-7$ & SS & 7.69E-08 & \\
\hline \multirow[t]{2}{*}{$\alpha-\mathrm{Fe}_{2} \mathrm{O}_{3}$} & 2.74 & $1.72 \pm 0.54 \mathrm{E}-5$ & Ini & 3.30E-06 & 8.27E17 \\
\hline & & 0 & SS & 0 & \\
\hline \multirow[t]{2}{*}{$\mathrm{ZnO}$} & 2.75 & $4.08 \pm 0.98 \mathrm{E}-6$ & Ini & 7.80E-07 & 3.49E17 \\
\hline & & 0 & SS & 0 & \\
\hline \multirow{2}{*}{$\mathrm{SiO}_{2} \mathrm{TiO}_{2}$} & 4.80 & 0 & Ini & 0 & 0 \\
\hline & 12.74 & & SS & 0 & 0 \\
\hline \multirow[t]{2}{*}{ Mineral dust* } & - & - & Ini & 3.84E-07 & $8.00 \mathrm{E} 17$ \\
\hline & & & SS & 2.86E-08 & \\
\hline
\end{tabular}

Ini - the initial uptake coefficient; SS - the steady state uptake coefficient at $30 \mathrm{~min}$.

* The value for mineral dust was calculated based on the uptake coefficients of individual oxide and its fraction in authentic mineral dust.

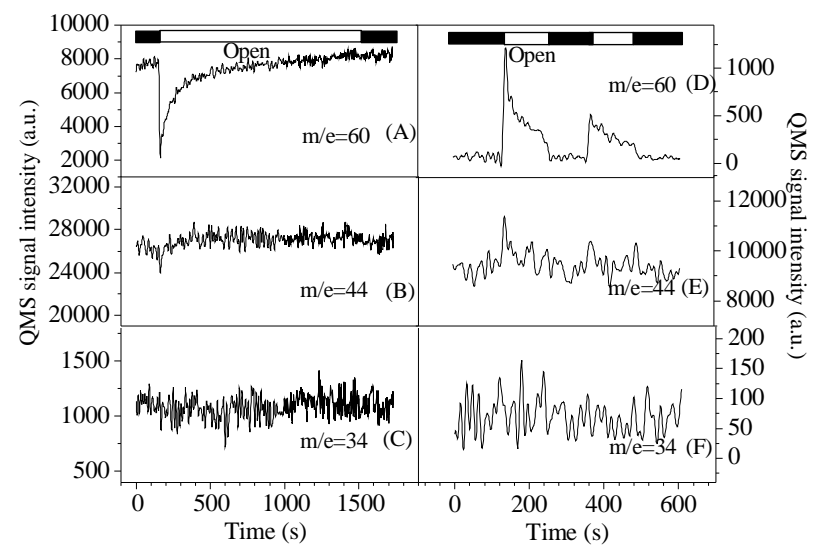

Fig. 2. The heterogeneous reaction of OCS on $141.3 \mathrm{mg}$ of $\alpha-\mathrm{Fe}_{2} \mathrm{O}_{3}$ at $300 \mathrm{~K}$ (left side) and the in situ desorption of surface species in the end of uptake (right side).

out on $\mathrm{ZnO}$ and $\alpha-\mathrm{Fe}_{2} \mathrm{O}_{3}$. After the uptake experiment finished, the samples were outgassed at $3.0 \pm 1.0 \times 10^{-7}$ Torr and at $300 \mathrm{~K}$ for $18 \mathrm{~h}$. Then repeated uptake experiments were performed at $300 \mathrm{~K}$. As can be seen from Fig. S3, the adsorption of OCS on $\mathrm{ZnO}$ was clearly observed in the 1st run, while it became very weak in the 2 nd and the 3 rd runs. In contrast, OCS could reversibly adsorb on $\alpha-\mathrm{Fe}_{2} \mathrm{O}_{3}$. These results further confirmed the reversible adsorption of OCS on $\alpha-\mathrm{Fe}_{2} \mathrm{O}_{3}$ and irreversible adsorption on $\mathrm{ZnO}$.

In our previous work (Liu et al., 2007b), we found that when $\alpha-\mathrm{Fe}_{2} \mathrm{O}_{3}$ and $\mathrm{ZnO}$ were exposed to OCS at $303 \mathrm{~K}$ for a long time (120 min), the consumption of surface hydroxyl was prominent and accompanied by the weak absorbance of $\mathrm{HSCO}_{2}^{-}, \mathrm{HCO}_{3}^{-}$and $\mathrm{SO}_{4}^{2-}$ etc. Chen et al. (2007) also ob-

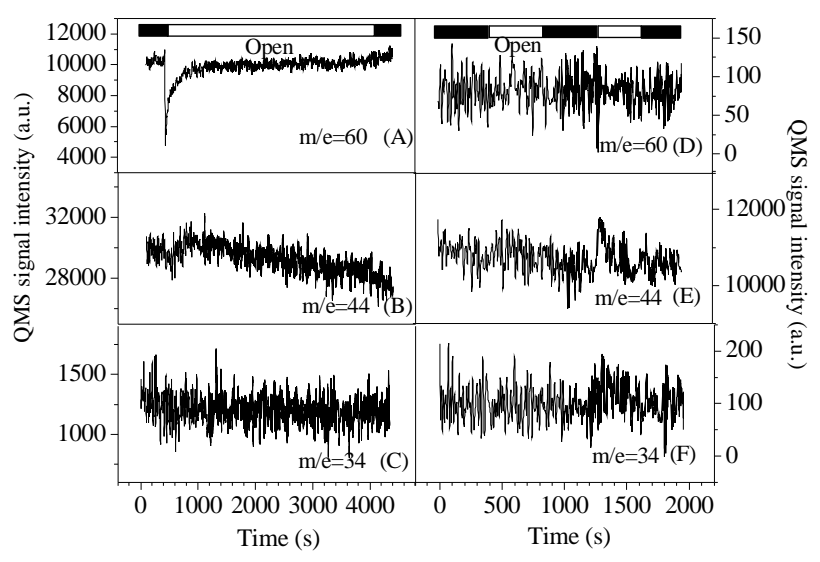

Fig. 3. The heterogeneous reaction of OCS on $200.9 \mathrm{mg}$ of $\mathrm{ZnO}$ at $300 \mathrm{~K}$ (left side) and the in situ desorption of surface species in the end of uptake (right side).

served the consumption of OCS on $\alpha-\mathrm{Fe}_{2} \mathrm{O}_{3}$ for $24 \mathrm{~h}$, while the reaction rate constant measured was very low. It should be noted that in the previous works (Chen et al., 2007; Liu et al., 2007b), the uptake experiments were investigated using DRIFTS reactors with a long exposure time. Thus, they obtained integrated signals for the reaction on $\alpha-\mathrm{Fe}_{2} \mathrm{O}_{3}$, while the differential signals was gained within a $0.6 \mathrm{~s}$ time-scale in this work. Therefore, the uptake experiments performed in the Knudsen cell reactor represents a more initial and fresh state for oxides. According to uptake experiments performed in this work, we deduced that OCS should be mainly reversibly adsorbed on $\alpha-\mathrm{Fe}_{2} \mathrm{O}_{3}$ and irreversibly adsorbed on $\mathrm{ZnO}$, and the hydrolysis and oxidation reactions on them are negligible because the reactions of OCS on $\alpha-\mathrm{Fe}_{2} \mathrm{O}_{3}$ and 


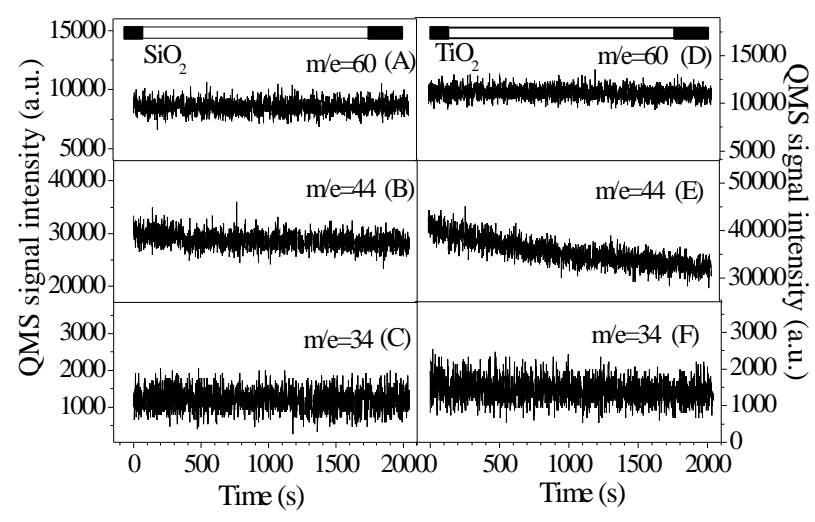

Fig. 4. The heterogeneous reactions of OCS on $350.5 \mathrm{mg} \mathrm{SiO} 2$ and $400.0 \mathrm{mg} \mathrm{TiO}$, respectively. The left side is the uptake curve of OCS by $\mathrm{SiO}_{2}$, and the right side is the uptake curve of OCS by $\mathrm{TiO}_{2}$.

$\mathrm{ZnO}$ were also found slow even in the DRIFTS reactors.

$\mathrm{SiO}_{2}$ and $\mathrm{TiO}_{2}$. The uptake profiles of OCS on $\mathrm{SiO}_{2}$ and $\mathrm{TiO}_{2}$ are shown in Fig. 4. When $350.5 \mathrm{mg}$ of $\mathrm{SiO}_{2}$ and $400.0 \mathrm{mg}$ of $\mathrm{TiO}_{2}$ were exposed to the feed gas, respectively, no uptakes of OCS were observed in Figs. 4a and d. The changes of $\mathrm{CO}_{2}$ and $\mathrm{H}_{2} \mathrm{~S}$ were also negligible when the sample cover was opened. In our previous work, we had observed the consumption of OCS over $\mathrm{SiO}_{2}$ and $\mathrm{TiO}_{2}$ in a closed system were slightly faster than that over the background of in situ DRIFTS reactor chamber (Liu et al., 2007b). As discussed above, the difference between KCMS experiments and in situ DRIFTS experiments is derived from the different experimental methods. KCMS is a differential reactor, when the change of the flow rate of OCS in the reactor is lower than $2 \times 10^{14}$ molecules s ${ }^{-1}(3 \sigma)$, the QMS cannot detect any change of its signal intensity, while the in situ DRIFTS reactor chamber in the closed system belongs to an integrated reactor, and the consumption of OCS is the accumulation of infrared signals at several minutes or several hours level. Therefore, we can conclude that even though the heterogeneous reactions of OCS can take place on $\mathrm{SiO}_{2}$ and $\mathrm{TiO}_{2}$, they are very slow and have little contribution to the sink of OCS in the troposphere.

\subsection{Identification of other surface species and reaction pathway}

Using DRIFTS, we have identified the surface species including $\mathrm{HSCO}_{2}^{-}, \mathrm{HS}, \mathrm{CO}_{3}^{2-}, \mathrm{HCO}_{3}^{-}, \mathrm{SO}_{3}^{2-}$ and $\mathrm{SO}_{4}^{2-}$ etc. for the hydrolysis and oxidation of OCS on most of these oxides (He et al., 2005; Liu et al., 2006, 2007a, b, 2009a). Wu et al. $(2004,2005)$ also observed the formation of element sulfur by XPS. In order to identify other surface species during heterogeneous reactions and to further clarify the difference between the reaction pathway of OCS on $\mathrm{CaO}$ and that on $\mathrm{MgO}$ (as shown in Figs. 1 and S2), the surface sulfur species were investigated by diffuse reflectance UV-vis spectroscopy. After the $\mathrm{CaO}$ and $\mathrm{MgO}$ samples were exposed to $1000 \mathrm{ppmv}$ of OCS/air in $100 \mathrm{~mL} / \mathrm{min}$ at $300 \mathrm{~K}$ for $9 \mathrm{~h}$, the diffuse reflectance UV-vis spectra were collected immediately using the corresponding pure oxides as reference samples. The UV-vis spectra are shown in Fig. 5. The peak at $217 \mathrm{~nm}$ is assigned to surface $\mathrm{HSO}_{3}^{-}$, and the peak at $226 \mathrm{~nm}$ is ascribed to surface $\mathrm{S}^{2-}$ (Davydov, 2003). The abroad bands around $260-280 \mathrm{~nm}$, and $340 \mathrm{~nm}$ were also observed, and they are assigned to the absorbance bands of element sulfur (Davydov, 2003). This result demonstrates that $\mathrm{H}_{2} \mathrm{~S}$, as the hydrolysis product, can further decompose into elemental sulfur and sulfide species on the mineral oxides.

As can be seen in Fig. 5, surface $\mathrm{HSO}_{3}^{-}$and $\mathrm{S}^{2-}$ are common surface sulfur containing species for the heterogeneous reaction of OCS on both $\mathrm{CaO}$ and $\mathrm{MgO}$. The formation of $\mathrm{HSO}_{3}^{-}$is well supported by the DRISFTS results (He et al., 2005; Liu et al., 2006, 2007a, b, 2009a). In Fig. 5a, very strong broad bands attributing to the element sulfur were observed on $\mathrm{CaO}$, which means element sulfur should also be one of the surface products for the heterogeneous reaction of OCS on $\mathrm{CaO}$. It should be noted that $\mathrm{S}^{2-}$ was also observed for the OCS treated $\mathrm{CaO}$ sample. Therefore, we postulate that element $\mathrm{S}$ might be the further oxidization product of $\mathrm{S}^{2-}$, while $\mathrm{S}^{2-}$ is from the decomposition of $\mathrm{H}_{2} \mathrm{~S}$ or surface HS. This assumption is confirmed by the result that there was no desorption of $\mathrm{H}_{2} \mathrm{~S}$ found after heterogeneous reaction of OCS on $\mathrm{CaO}$ (Fig. 3f). Additionally, after heterogeneous reaction, the sample was purged further with pure $\mathrm{O}_{2}$ for $9 \mathrm{~h}$, the absorbance intensity of elemental sulfur decreased greatly (data not shown). This means that the newly formed sulfur can be further oxidized to high state species. As for $\mathrm{MgO}$, although element $\mathrm{S}$ can be also observed (Fig. 5b), its relative content was much lower than that on $\mathrm{CaO}$. It implies a low decomposition rate of surface $\mathrm{HS}$ to $\mathrm{S}$ on $\mathrm{MgO}$, thus, the formation and desorption of $\mathrm{H}_{2} \mathrm{~S}$ was very prominent (Fig. S2), and the surface HS was also observable in the in situ infrared spectra (Liu et al., 2007a). As for OCS treated $\alpha-\mathrm{Fe}_{2} \mathrm{O}_{3}$ and $\mathrm{ZnO}$, the UV-vis signal (data not shown) was weak due to their low reactivity.

According to the perturbation theory and orbital mixing, the decomposition reactivity of $\mathrm{H}_{2} \mathrm{~S}$ on mineral oxides was found to be related to the band gap of oxides. The lower the band gap of the oxide, the higher the adsorption activity and decomposition reactivity of $\mathrm{H}_{2} \mathrm{~S}$ (Rodriguez et al., 1998). The band gap of $\mathrm{CaO}$ is $6.8 \mathrm{eV}$, while it is $7.7 \mathrm{eV}$ for $\mathrm{MgO}$ (Baltache et al., 2004), suggesting that the decomposition reaction of $\mathrm{H}_{2} \mathrm{~S}$ on $\mathrm{CaO}$ should be more facile than that on $\mathrm{MgO}$. Therefore, we can deduce that the absence of $\mathrm{H}_{2} \mathrm{~S}$ in the products for the heterogeneous reaction of OCS on $\mathrm{CaO}$ should be ascribed to the formation of $\mathrm{CaS}$ and the element sulfur on the surface. 

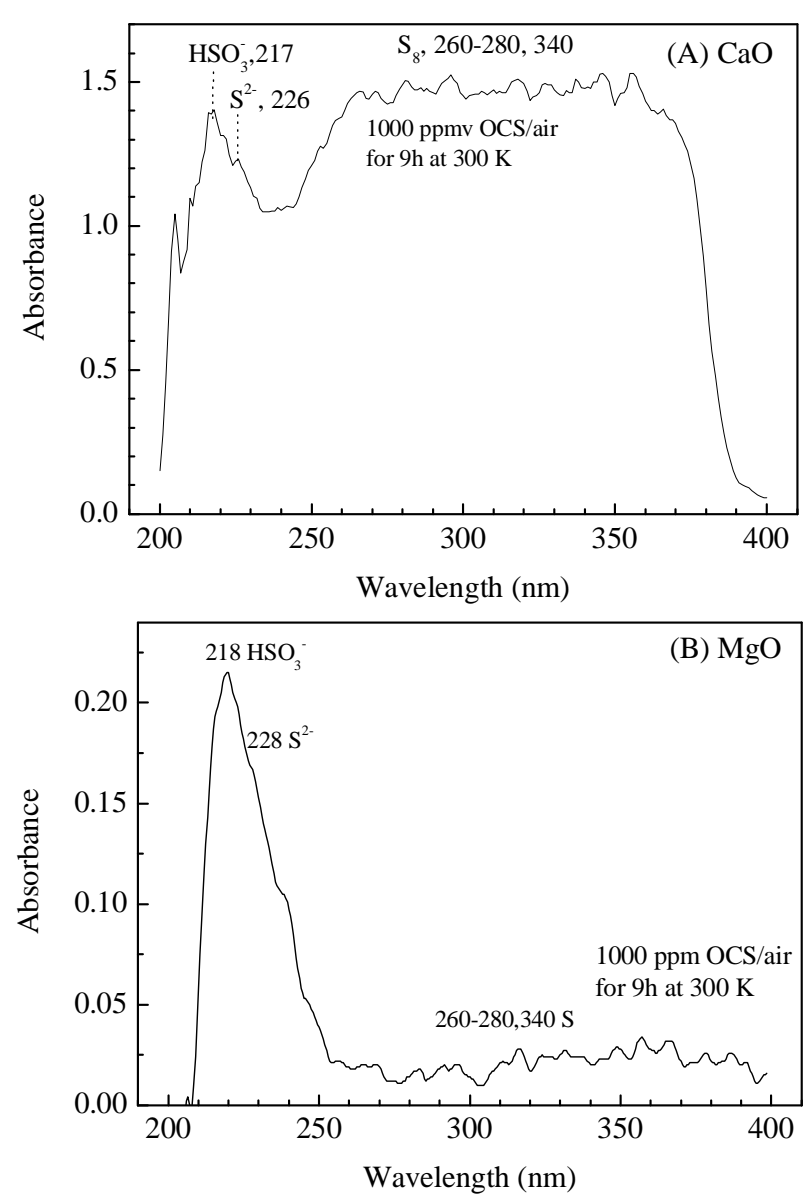

Fig. 5. Diffuse reflectance UV-vis spectra of (a) $\mathrm{CaO}$, and (b) $\mathrm{MgO}$ after exposed to $1000 \mathrm{ppmv}$ of OCS in air for $9 \mathrm{~h}$.

It should be noted that $\mathrm{Fe}$ and $\mathrm{Zn}$ are typical sulphophile elements. It has been found that $\mathrm{H}_{2} \mathrm{~S}$ undergoes complete decomposition on $\mathrm{ZnO}$ to form sulfide at $300 \mathrm{~K}$ (Lin et al., 1992; Rodriguez et al., 1998). On the other hand, the small band gap of $\mathrm{ZnO}(3.4 \mathrm{eV})$ (Rodriguez et al., 1998) also implied its strong decomposition reactivity for $\mathrm{H}_{2} \mathrm{~S}$ to surface sulfide or sulfur species. As for $\alpha-\mathrm{Fe}_{2} \mathrm{O}_{3}$, the band gap is $2.2 \mathrm{eV}$, which means a stronger decomposition reactivity for $\mathrm{H}_{2} \mathrm{~S}$ to surface sulfide or sulfur species. However, in our previous work, we have found that reactivity of OCS on mineral oxides depends on the basicity of oxides, i.e., the stronger the basicity of oxide, the higher the reactivity of OCS on it (Liu et al., 2007b and 2009b). $\alpha-\mathrm{Fe}_{2} \mathrm{O}_{3}$ and $\mathrm{ZnO}$ are typical acidic oxides, suggesting that they have very low heterogeneous reactivity. On the other hand, in Figs. 2 and 3, the desorption of $\mathrm{CO}_{2}$ on $\alpha-\mathrm{Fe}_{2} \mathrm{O}_{3}$ and $\mathrm{ZnO}$ was negligible, thus, the amount of $\mathrm{H}_{2} \mathrm{~S}$ produced in heterogeneous reaction should be negligible. In particular, the reversible adsorption of OCS on $\alpha-\mathrm{Fe}_{2} \mathrm{O}_{3}$ was observed in Fig. 2. Therefore, even if hydrolysis of OCS could occur on $\alpha-\mathrm{Fe}_{2} \mathrm{O}_{3}$ and $\mathrm{ZnO}$, the surface sulfide or element sulfur species, which is easily formed on

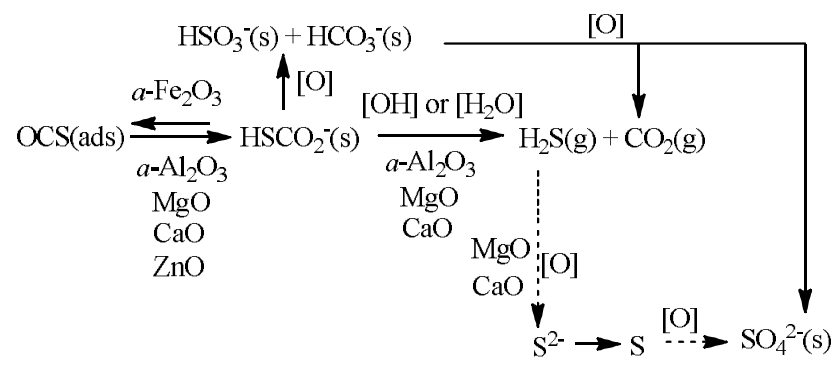

Scheme 1. Reaction pathway for OCS on different mineral oxides.

these oxides, should lead to the quick deactivation by blocking the active site for the heterogeneous reaction of OCS on $\alpha-\mathrm{Fe}_{2} \mathrm{O}_{3}$ and $\mathrm{ZnO}$. Thus, the oxides with stronger basicity and lower decomposition reactivity for $\mathrm{H}_{2} \mathrm{~S}$ to surface sulfide or element sulfur species should show higher catalytic activities for the decomposition of adsorbed OCS than these oxides with anti-properties. The main heterogeneous process of OCS on $\alpha-\mathrm{Fe}_{2} \mathrm{O}_{3}$ and $\mathrm{ZnO}$ may be adsorption process, and catalytic reaction of OCS is less important.

Based on the above results and the previous works (Chen et al., 2007; He et al., 2005; Liu et al., 2006, 2007a, b, 2009), the reaction pathway for OCS on mineral oxides was summarized in Scheme 1. Catalytic reactions obviously occur on $\mathrm{MgO}, \mathrm{CaO}$ and $\alpha-\mathrm{Al}_{2} \mathrm{O}_{3}$. The key intermediate of $\mathrm{HSCO}_{2}^{-}$ can be directly oxidized to $\mathrm{HSO}_{3}^{-}, \mathrm{HCO}_{3}^{-}$and $\mathrm{SO}_{4}^{2-}$. It can also hydrolyze to form $\mathrm{H}_{2} \mathrm{~S}$ and $\mathrm{CO}_{2}$. Gaseous $\mathrm{H}_{2} \mathrm{~S}$ can further decompose to sulfide compound (MS) and element sulfur on $\mathrm{MgO}$ and $\mathrm{CaO}$, respectively. The surface sulfur species including sulfur, sulfide and sulfite can be finally oxidized to sulfate. Irreversible and adsorption of OCS on $\mathrm{ZnO}$ and reversible adsorption of OCS on $\alpha-\mathrm{Fe}_{2} \mathrm{O}_{3}$ can take place at $300 \mathrm{~K}$. As for $\mathrm{TiO}_{2}$ and $\mathrm{SiO}_{2}$, no uptake of OCS was observed. The reactivity of OCS on the mineral oxides depends on both the basicity of mineral oxides and decomposition reactivity for $\mathrm{H}_{2} \mathrm{~S}$ of these oxides.

\subsection{Reaction kinetics for the heterogeneous reaction of OCS on mineral oxides}

Uptake coefficient, which demonstrates the activity of adsorption or reaction for heterogeneous process, was the most commonly used kinetic parameter in atmospheric chemistry and also in model studies. Uptake coefficient $(\gamma)$ is defined by Eq. (1) (Underwood et al., 2000).

$\gamma=\frac{-\frac{\mathrm{d} n}{\mathrm{~d} t}}{\omega}$

where $-\frac{\mathrm{d} n}{\mathrm{~d} t}$ is the number of molecules lost from the gas phase per second due to the collision between gas molecules and solid surface (molecules $\mathrm{s}^{-1}$ ); $\omega$ is the total number of gas-surface collisions per second. Based on the Knudsen cell experimental results, the observed uptake coefficients, $\gamma_{\mathrm{obs}}$, of OCS on mineral oxides characterised by the loss of 
gaseous OCS can be calculated from Knudsen cell equation (Barone et al., 1997; Beichert and Finlayson-Pitts, 1996; Liu et al., 2008b, c; Underwood et al., 2000).

$\gamma_{\mathrm{obs}}=\frac{A_{h}}{A_{s}} \frac{\left(I_{0}-I\right)}{I}$

where $A_{h}$ is the effective area of the escape aperture $\left(\mathrm{cm}^{2}\right)$; $A_{s}$ is the geometric area of the sample holder $\left(\mathrm{cm}^{2}\right)$; and $I_{0}$ and $I$ are the mass spectral intensities of OCS with the sample holder closed and open, respectively. If the reactant gas can diffuse into the underlying layers for the multilayer powder sample, the effective collision area should be considered. Usually, the effective surface area was used. And then the true uptake coefficients, $\gamma_{t}$ (BET), can be calculated from Eq. (3)

$\gamma_{t}=$ slope $\cdot\left(\frac{A_{s}}{S_{\mathrm{BET}}}\right)$

where slope is the slope of plot of $\gamma_{\mathrm{obs}}$ and sample mass in linear region $\left(\mathrm{mg}^{-1}\right) ; S_{\mathrm{BET}}$ is the specific surface area of particle sample $\left(\mathrm{cm}^{2} \mathrm{mg}^{-1}\right)$ (Carlos-Cuellar et al., 2003).

The observed uptake coefficients calculated through the geometric area of the sample holder at the initial time (referred as $\gamma_{\text {obs }}$ (Initial)) and at steady state $\left(\gamma_{\text {obs }}\right.$ (Steady state)) were plotted along with sample mass through the origin and the results are shown in Fig. 6a-c. As for $\alpha-\mathrm{Fe}_{2} \mathrm{O}_{3}$ and $\mathrm{ZnO}$, $\gamma_{\text {obs }}$ (Initial) and adsorption capacities are given in Fig. 6d and e. The error bar was $15 \%$ obtained from the repeated experiments. It can be seen from Fig. 8 that there was a strong linear dependence of $\gamma_{\text {obs }}$ or adsorption capacity versus sample mass for all tested mineral oxides. It means the underlying layers of these oxide samples also contribute to the heterogeneous uptake and catalytic reaction under these experimental conditions. Therefore, $\gamma_{t}(\mathrm{BET})$ can be calculated from the slope and specific area of oxides sample via Eq. (3). $\gamma_{t}(\mathrm{BET})$ values of OCS on different oxides are presented in Table 1. $\gamma_{t}$ (Initial) values were in the order: $\alpha-\mathrm{Fe}_{2} \mathrm{O}_{3}>\mathrm{ZnO}$ $>\mathrm{CaO}>\alpha-\mathrm{Al}_{2} \mathrm{O}_{3}>\mathrm{MgO}>\mathrm{SiO}_{2}, \mathrm{TiO}_{2}$, while the order of $\gamma_{t}$ (Steady state) is $\mathrm{MgO}>\alpha-\mathrm{Al}_{2} \mathrm{O}_{3}, \mathrm{CaO}>\mathrm{ZnO}, \alpha-\mathrm{Fe}_{2} \mathrm{O}_{3}$, $\mathrm{SiO}_{2}, \mathrm{TiO}_{2}$.

When the intensity of mass spectrometer for OCS was corrected with flow rate of molecules and the consumption of OCS by catalytic reaction was subtracted, the adsorption capacity of OCS on different oxides was calculated (Table 1). The values of initial uptake coefficients of OCS on $\alpha-\mathrm{Al}_{2} \mathrm{O}_{3}$, $\mathrm{MgO}, \mathrm{CaO}, \alpha-\mathrm{Fe}_{2} \mathrm{O}_{3}$ and $\mathrm{ZnO}$ were much greater than that of steady state uptake coefficients. Despite large initial uptake coefficients for $\alpha-\mathrm{Fe}_{2} \mathrm{O}_{3}$ and $\mathrm{ZnO}$, their steady state uptake coefficients decreased to zero. As discussed above, the initial uptake was mainly owing to the adsorption process, while the steady state uptake was related to the catalytic reaction. It means that only a part of adsorbed OCS can be transformed to $\mathrm{HSCO}_{2}^{-}$, and then it decomposes into $\mathrm{CO}_{2}$ and $\mathrm{H}_{2} \mathrm{~S}$. The decomposition of $\mathrm{HSCO}_{2}^{-}$is a rate determining step (Liu et al., 2008c). On the other hand, the surface species such as $\mathrm{HCO}_{3}^{-}, \mathrm{CO}_{3}^{2-}, \mathrm{S}^{2-}, \mathrm{S}, \mathrm{SO}_{3}^{2-}$ and $\mathrm{SO}_{4}^{2-}$ also induced the decline of catalytic reactivity. Therefore, the initial uptake coefficients on all of these oxides are much higher than their steady state uptake coefficients. Among these surface species, sulfide species have a prominent effect, especially on $\mathrm{ZnO}$ and $\mathrm{CaO}$. Although the initial uptake coefficients were large on these oxides, the steady state uptake coefficients (shown in Table 1) were small because the sulfide or sulfur species could hardly desorb from the surface. In addition, as mentioned above, the heterogeneous reactivity of OCS on mineral dust is in relation to the surface basicity of oxides (Liu et al., 2007b and 2009b). The basicity sequence for these oxides is: $\mathrm{CaO}>\mathrm{MgO}>\alpha-\mathrm{Al}_{2} \mathrm{O}_{3}>$ $\mathrm{ZnO}, \alpha-\mathrm{Fe}_{2} \mathrm{O}_{3}, \mathrm{SiO}_{2}, \mathrm{TiO}_{2}$ (Liu et al., 2007b). The order of steady state uptake coefficients also supports the forenamed assumption. Except for $\mathrm{CaO}$, which is related to the deactivation of surface sulfur species, the order of steady state uptake coefficients is almost the same as the basicity sequence of mineral oxides. Therefore, we can deduce that the alkali elements and alkaline-earth metals in the authentic atmospheric particles should promote the heterogeneous reaction of OCS in the troposphere.

According to the true uptake coefficients of single oxide and the mineral composition of authentic atmospheric particulate matter (He et al., 2005; Usher et al., 2003a), the true uptake coefficient of authentic atmospheric mineral dust can be estimated from Eq. (4).

$\gamma_{\text {dust }}=\sum f_{i} \gamma_{i}$

where, $\gamma_{\text {dust }}$ is the true uptake coefficient for mineral dust; $f_{i}$ is the fraction of oxide in atmospheric mineral dust (He et al., 2005); $\gamma_{i}$ is the true uptake coefficient of corresponding oxide (Usher, et al., 2002). The $\gamma_{\text {dust }}$ was calculated to be from $3.84 \times 10^{-7}$ (initial) to $2.86 \times 10^{-8}$ (steady state). This value is comparable to the uptake coefficient of $\mathrm{NO}_{2}$ on mineral dust $\left(10^{-7}-10^{-8}\right)$ (Ullerstmal et al., 2003; Underwood, et al., 1999, 2000).

In our previous work (Liu et al., 2007b), we have found that the heterogeneous reaction of OCS on mineral oxides is a first-order reaction. Therefore, the reaction rate constant can be calculated from Eq. (5) (Ravishankara, 1997).

$k_{\text {dust }}=\frac{\bar{v} \cdot \gamma_{\text {dust }} \cdot \mathrm{SA}}{4}$

Here, $k_{\text {dust }}$ is the rate constant for the first-order reaction $\left(\mathrm{s}^{-1}\right) ; \bar{v}$ is the average velocity of OCS molecules $\left(\mathrm{m} \mathrm{s}^{-1}\right) ; \gamma_{\text {dust }}$ is the true uptake coefficient of mineral dust $\left(\mathrm{m}^{2} \mathrm{~m}^{-3}\right)$; SA is the globally-averaged dust surface area $\left(150 \mu \mathrm{m}^{2} \mathrm{~cm}^{-3}\right)$ (de Reus et al., 2000; Frinak et al., 2004). The rate constants of OCS on mineral dust in the troposphere were estimated to be $4.69 \times 10^{-9} \mathrm{~s}^{-1}$ (initial) and $3.49 \times 10^{-10} \mathrm{~s}^{-1}$ (steady state). 

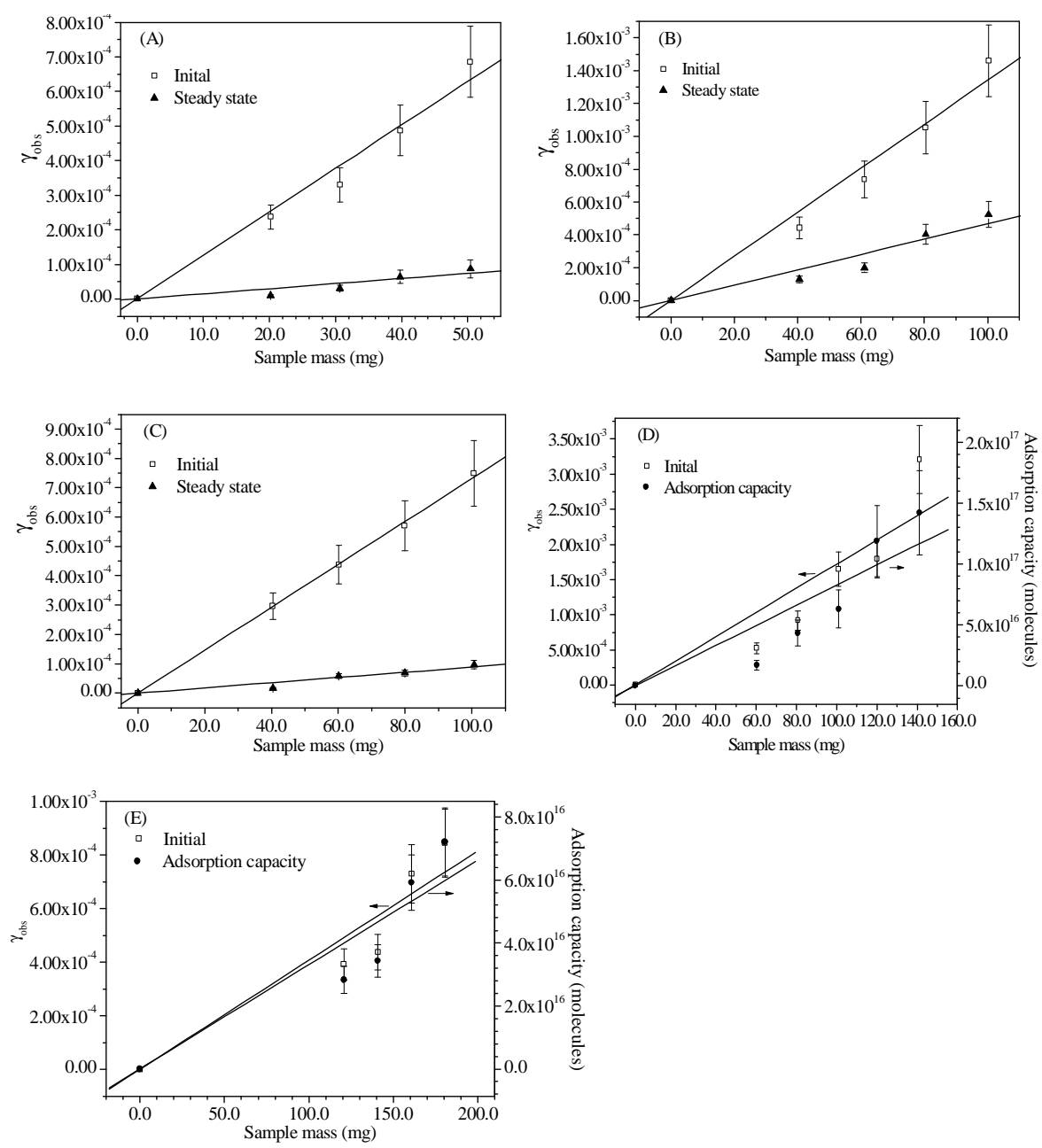

Fig. 6. The linear mass dependence between uptake coefficients or saturated adsorption capacity and sample mass for OCS on mineral oxides at $300 \mathrm{~K}$. (a) $\alpha-\mathrm{Al}_{2} \mathrm{O}_{3}$, (b) $\mathrm{MgO}$, (c) $\mathrm{CaO}$, (d) $\alpha-\mathrm{Fe}_{2} \mathrm{O}_{3}$, (e) $\mathrm{ZnO}$.

\section{Conclusions and atmospheric implications}

In this work, the heterogeneous reactions of OCS on typical mineral oxides were investigated by using Knudsen cell reactor and diffuse reflectance UV-vis spectroscopy. Catalytic hydrolysis and oxidation reaction were observed on $\mathrm{MgO}$, $\mathrm{CaO}$ and $\alpha-\mathrm{Al}_{2} \mathrm{O}_{3}$, and reversible adsorption of OCS on $\alpha$ $\mathrm{Fe}_{2} \mathrm{O}_{3}$ and irreversible adsorption on $\mathrm{ZnO}$ were observed, whereas no uptake of OCS was observed on $\mathrm{TiO}_{2}$ and $\mathrm{SiO}_{2}$. For $\mathrm{CaO}$, the decomposition reactivity of hydrolysis product $\left(\mathrm{H}_{2} \mathrm{~S}\right)$ is stronger than that on $\mathrm{MgO}$ and $\alpha-\mathrm{Al}_{2} \mathrm{O}_{3}$, which leads to the obvious deactivation of hydrolysis of OCS on $\mathrm{CaO}$ at steady state. The uptake coefficients (BET) of OCS on these oxides were measured to be in the range of $10^{-7}$ $10^{-8}$, and are comparable with the uptake of $\mathrm{NO}_{2}$ on mineral dust.

Because the initial uptake is mainly due to adsorption, the heterogeneous process of OCS on mineral dust could be divided into adsorption and catalytic reaction. In the real at- mosphere, the uptake coefficients at steady state should be more representative than the initial uptake coefficients because once emitted into the atmosphere the fresh dust samples were often quickly aged by reactant gases. With the assumption of the total OCS mass of $4.63 \mathrm{Tg}$ in the troposphere (Chin and Davis, 1995), and the first-order reaction rate constants of OCS on mineral dust (steady state), the global flux of OCS on mineral dust due to heterogeneous reactions was calculated to be $0.05 \mathrm{Tg} \mathrm{yr}^{-1}$. Thus, this value, which is relating to the catalytic activity of dust, is important to access the sinks of OCS due heterogeneous reaction.

Based on the adsorption capacity of each oxide and the mass fraction of oxide in atmospheric mineral dust, the equivalent adsorption capacity of mineral dust was calculated to be $8.00 \times 10^{17}$ molecules $\mathrm{g}^{-1}$ by Eq. (6).

$A c_{\mathrm{dust}}=\sum_{i} f_{i} A c_{i}$ 
where $A c$ is the adsorption capacity. The adsorption process might contribute the global sink of $0.08-0.24 \mathrm{Tg} \mathrm{OCS} \mathrm{year}^{-1}$ with the deposit of mineral dust (1000-3000 Tg year $^{-1}$ ). Considering both adsorption and catalytic reactions, the total sink of OCS due to mineral dust should be $0.13-$ $0.29 \mathrm{Tg}$ year $^{-1}$ via the adsorption and catalytic reaction of mineral dust. Comparing with other sinks, this value might be equivalent to the annual flux for reaction of OCS with .OH of $0.10 \mathrm{Tg} \mathrm{yr}^{-1}$ (Watts, 2000). Even though only the consumption by catalytic reaction was considered, the contribution of mineral dust to the sink of OCS should also be not ignored.

The uptake coefficient of OCS on mineral dust estimated by using the uptake coefficients of OCS on the individual components and their mass fraction in the mineral dust (Eq. 4) contains a considerable uncertainty. Therefore, in the future work, the uptake of OCS on realistic dust samples such as Sahara dust, Arizona Test dust or other authentic dust samples should be considered. On the other hand, the value of $150 \mu \mathrm{m}^{2} \mathrm{~cm}^{-3}$ was taken from one flight airplane study (de Reus et al., 2000) and it is more representative of a regional dust layer rather than a global average. Unfortunately, the global mean dust loading is unavailable in published literature. The estimating method for the sink of OCS owing to heterogeneous reaction on mineral dust, therefore, is also a middle course of action. Additionally, the real atmosphere is very complicated. The relative humidity and coexisting gases such as $\mathrm{CO}_{2}, \mathrm{NO}_{\mathrm{x}}, \mathrm{SO}_{2}$, organic compounds and alkali metal etc., may have a complex effect on the heterogeneous reaction of OCS on mineral dust. For example, Vlasenko et al. (2006) and Liu et al. (2008a) have found out that water soluble nitric acid is taken more readily by dust surrogates at higher relative humidity due to an increasing degree of salvation of the more basic minerals and enhancing ionic mobility for segregation or crystallization of nitrate at the surface. However, our recent work (Liu et al., 2009b) demonstrates that adsorbed water on mineral oxides should restrict the heterogeneous reaction of OCS at atmospheric relative humidity due to competitive adsorption between $\mathrm{H}_{2} \mathrm{O}$ and OCS onto the reactive site (surface $\mathrm{OH}$ ). The basic membrane and the uncovered part by water still have catalytic activity. Considering the effect of water vapour and the aging processes on the heterogeneous uptake of OCS on mineral dust, therefore, the sink of OCS on mineral dust estimated in this work should be an upper limit. In this study, we did not consider alkali metal ( $\mathrm{Na}$ and $\mathrm{K}$ ) in the oxides. However, our previous work found that strong basicity of oxide is in favour of the heterogeneous reaction of OCS. It means that the alkali metal should also promote this reaction. Therefore, our results in this study only present the case under clean and dry conditions. Heterogeneous reactions of OCS on mineral dust in the troposphere should be considered for evaluating the atmospheric behaviour of OCS for a further study.

\section{Supplementary material related to this article is available online at: http://www.atmos-chem-phys.net/10/10335/2010/ acp-10-10335-2010-supplement.pdf.}

Acknowledgements. This research was financially supported by the National Natural Science Foundation of China (40775081, 20937004, and 50921064), and the Special Co-construction Project of Beijing Municipal Commission of Education. Yongchun Liu would also like to thank the President Scholarship of Chinese Academy of Sciences for the financial support.

Edited by: M. Ammann

\section{References}

Anderson, T. L., Charison, R. J., Schwartz, S. E., Knutti, R., Boucher, O., Rodhe, H., and Heintzenberg, J.: Climate forcing by aerosols - a hazy picture, Science, 300, 1103-1104, 2003.

Andreae, M. O. and Crutzen, P. J.: Atmospheric aerosols: Biogeochemical sources and role in atmospheric chemistry, Science, 276, 1052-1058, 1997.

Aubin, D. G. and Abbatt, J. P.: Laboratory measurements of thermodynamics of adsorption of small aromatic gases to n-hexane soot surfaces, Environ. Sci. Technol., 40, 179-187, 2006.

Baltache, H., Khenata, R., Sahnoun, M., Driz, M., Abbar, B., and Bouhafs, B.: Full potential calculation of structural, electronic and elastic properties of alkaline earth oxides $\mathrm{MgO}, \mathrm{CaO}$ and SrO, Phys. B, 344, 334-342, 2004.

Barone, S. B., Zondlo, M. A., and Tolbert, M. A.: A kinetic and product study of hydrolysis of $\mathrm{ClONO}_{2}$ on type Ia polar stratospheric cloud materials at 185 K, J. Phys. Chem. A, 101, 86438652, 1997.

Beichert, P. and Finlayson-Pitts, B. J.: Knudsen cell studies of the uptake of gaseous $\mathrm{HNO}_{3}$ and other oxides of nitrogen on solid $\mathrm{NaCl}$ : The role of surface-adsorbed water, J. Phys. Chem., 100, 15218-15228, 1996.

Carlos-Cuellar, S., Li, P., Christensen, A. P., Krueger, B. J., Burrichter, C., and Grassian, V. H.: Heterogeneous uptake kinetics of volatile organic compounds on oxide surface using a Knudsen cell reactor: Adsorption of acetic acid, formaldehyde, and methanol on $\alpha-\mathrm{Fe}_{2} \mathrm{O}_{3}, \alpha-\mathrm{Al}_{2} \mathrm{O}_{3}$, and $\mathrm{SiO}_{2}$, J. Phys. Chem. A, 107, 4250-4261, 2003.

Chen, H. H., Kong, L. D., Chen, J. M., Zhang, R. Y., and Wang, L.: Heterogeneous uptake of carbonyl sulfide on hematite and hematite-NaCl mixtures, Environ. Sci. Technol., 41, 6484-6490, 2007.

Chin, M. and Davis, D. D.: A reanalysis of carbonyl sulfide as a source of stratospheric background sulfur aerosol, J. Geophys. Res., 100, 8993-9005, 1995.

Crutzen, P. J. The possible importance of CSO for the sulfate layer of the stratosphere, Geophys. Res. Lett., 3, 73-76, 1976.

Dentener, F. J., Carmichael, G. R., Zhang, Y., Lelieveld, J., and Crutzen, P. J.: Role of mineral aerosol as a reactive surface in the global troposphere, J. Geophys. Res., 101, 22869-22889, 1996.

de Reus, M., Dentener, F., Thomas, A., Borrmann, S., Ström, J., and Lelieveld, J.: Airborne observations of dust aerosol over the 
North Atlantic Ocean during ACE 2: Indications for heterogeneous ozone destruction, J. Geophys. Res., 105, 15263-15275, 2000.

Frinak, E. K., Wermeille, S. J., Mashburn, C. D., Tolbert, M. A., and Pursell, C. J.: Heterongeous reaciton of gaseous nitric acid on $\gamma$-phase iron(III) oxide, J. Phys. Chem. A, 108, 1560-1566, 2004.

Graf, H. F. The complex interaction of aerosols and clouds, Science, 303, 1309-1311, 2004.

He, H., Liu, J. F., Mu, Y. J., Yu, Y. B., and Chen, M. X.: Heterogeneous oxidation of carbonyl sulfide on atmospheric particles and alumina, Environ. Sci. Technol., 39, 9637-9642, 2005.

Jacob, D. J.: Heterogeneous chemistry and tropospheric ozone, Atmos. Environ., 34, 2131-2159, 2000.

Jang, M., Czoschke, N. M., Lee, S., and Kamens, R. M.: Heterogeneous atmospheric aerosol production by acid-catalyzed particle reactions, Science, 298, 814-817, 2002.

Jones, A., Roberts, D. L., and Slingo, A.: A climate model study of indirect radiative forcing by anthoropogenic sulphate aerosols, Nature, 370, 450-453, 1994.

Lin, J. Y., May, J. A., Didziulis, S. V., and Solomon, E. I.: Variableenergy photoelectron spectroscopic studies of $\mathrm{H}_{2} \mathrm{~S}$ chemisorption on $\mathrm{Cu}_{2} \mathrm{O}$ and $\mathrm{ZnO}$ single-crystal surfaces: HS- bonding to copper (I) and zinc (II) sites related to catalytic poisoning, J. Am. Chem. Soc., 114, 4718-4727, 1992.

Liu, J. F., Yu, Y. B., Mu, Y. J., and He, H.: Mechanism of heterogeneous oxidation of carbonyl sulfide on $\mathrm{Al}_{2} \mathrm{O}_{3}$ : An in situ diffuse reflectance infrared Fourier transform spectroscopy investigation, J. Phys. Chem. B, 110, 3225-3230, 2006.

Liu, Y., Gibson, E. R., Cain, J. P., Wang, H., Grassian, V. H., and Laskin, A.: Kinetics of heterogeneous reaction of $\mathrm{CaCO}_{3}$ particles with gaseous $\mathrm{HNO}_{3}$ over a wide range of humidity, J. Phys. Chem. A, 112, 1561-1571, 2008a.

Liu, Y. C. and He, H.: Heterogeneous reactivity of carbonyl sulfide on $\alpha-\mathrm{Al}_{2} \mathrm{O}_{3}$ and $\gamma-\mathrm{Al}_{2} \mathrm{O}_{3}$, Atmos. Environ., 42, 960-969, $2008 \mathrm{~b}$

Liu, Y. C. and He, H.: Experimental and theoretical study of hydrogen thiocarbonate for heterogeneous reaction of carbonyl sulfide on magnesium oxide, J. Phys. Chem. A, 113, 3387-3394, 2009a.

Liu Y. C., He, H., and Ma, Q. X.: Temperature dependence of the heterogeneous reaction of carbonyl sulfide on magnesium oxide, J. Phys. Chem. A, 112, 2820-2826, 2008c.

Liu, Y. C., He, H., Xu, W. Q., and Yu, Y. B.: Mechanism of heterogeneous reaction of carbonyl sulfide on magnesium oxide, J. Phys. Chem. A, 111, 4333-4339, 2007a.

Liu, Y. C., Liu, J. F., He, H., Yu, Y. B., and Xue, L.: Heterogeneous oxidation of carbonyl sulfide on mineral oxides, Chinese Sci. Bull., 52, 2063-2071, 2007b.

Liu, Y., Ma, Q., and He, H.: Comparative study of the effect of water on the heterogeneous reactions of carbonyl sulfide on the surface of $\mathrm{a}-\mathrm{Al}_{2} \mathrm{O}_{3}$ and $\mathrm{MgO}$, Atmos. Chem. Phys., 9, 62736286, doi:10.5194/acp-9-6273-2009, 2009b.
Notholt, J., Kuang, Z., Rinsland, C. P., Toon, G. C., Rex, M., Jones, N., Albrecht, T., Deckelmann, H., Krieg, J., Weinzierl, C., Bingemer, H., Weller, R., and Schrems, O.: Enhanced upper tropical troposhperic COS: Impact on the stratospheric aerosol layer, Science, 300, 307-310, 2003.

Ravishankara, A. R. Heterogeneous and multiphase chemistry in the troposphere, Science, 276, 1058-1065, 1997.

Rodriguez, J. A., Chaturvedi, S., Kuhn, M., and Hrbek, J.: Reaction of $\mathrm{H}_{2} \mathrm{~S}$ and $\mathrm{S}_{2}$ with metal/oxide surfaces: Band-gap size and chemical reactivity, J. Phys. Chem. B, 102, 5511-5519, 1998.

Solomon, S., Sanders, R. W., Garcia, R. R., and Keys, J. G.: Increased chlorine dioxide over Antarctica caused by volcanic aerosols form Mount Pinatubo, Nature, 363, 245-248, 1993.

Turco, R. P., Whitten, R. C., Toon, O. B., Pollack, J. B., and Hamill, P.: OCS, stratospheric aerosols and climate, Nature, 283, 283$286,1980$.

Underwood, G. M., Li, P., Usher, C. R., and Grassian, V. H.: Determining accurate kinetic parameters of potentially important heterogeneous atmospheric reactions on solid particles surfaces with a Knudsen cell reactor, J. Phys. Chem. A, 104, 819-829, 2000.

Underwood, G. M., Miller, T. M., and Grassian, V. H.: Transmission FT-IR and Knudsen cell study of the heterogeneous reactivity of gaseous nitrogen dioxide on mineral oxide particles, J. Phys. Chem. A, 103, 6184-6190, 1999.

Usher, C. R., Al-Hosney, H., Carlos-Cuellar, S., and Grassian, V. H.: A laboratory study of the heterogeneous uptake and oxidation of sulfur dioxide on mineral dust particles, J. Geophys. Res., 107, 4713-4721, 2002.

Usher, C. R., Michel, A. E., and Grassian, V. H.: Reactions on mineral dust, Chem. Rev., 103, 4883-4939, 2003 a.

Usher, C. R., Michel, A. E., Stec, D., and Grassian, V. H.: Laboratory studies of ozone uptake on processed mineral dust, Atmos. Environ., 37, 5337-5347, 2003b.

Vlasenko, A., Sjogren, S., Weingartner, E., Stemmler, K., Gäggeler, H. W., and Ammann, M.: Effect of humidity on nitric acid uptake to mineral dust aerosol particles, Atmos. Chem. Phys., 6, 21472160, doi:10.5194/acp-6-2147-2006, 2006.

Watts, S. F. The mass budgets of carbonyl sulfide, dimethyl sulfide, carbon disulfide and hydrogen sulfide, Atmos. Environ., 34, 761779, 2000.

Wu, H. B., Wang, X., and Cheng, J. M.: Photooxidation of carbonyl sulfide in the presence of the typical oxides in atmospheric aerosol, Sci. China. Ser. B Chem., 48, 31-37, 2005.

Wu, H. B., Wang, X., Cheng, J. M., Yu, H. K., Xue, H. X., Pan X. X., and Hou, H. Q.: Mechanism of the heterogeneous reaction of carbonyl sulfide with typical components of atmospheric aerosol, Chinese Sci. Bull., 49, 1231-1235, 2004. 